\title{
Milk Yield, Somatic Cell Count, and Udder Measurements in Holstein Cows at Different Lactation Number and Months
}

\author{
A. Ceyhan ${ }^{\mathrm{a}, *}$, M. Cinar ${ }^{\mathrm{a}}$, \&U. Serbester ${ }^{\mathrm{b}}$ \\ aNigde University, The Vocational School of Bor \\ 51700 Bor/Nigde, Turkey \\ bDepartment of Animal Science, Cukurova University \\ 01330 Balcalı Sarıçam/Adana, Turkey \\ (Received 13-04-2015; Reviewed 22-05-2015; Accepted 23-06-2015)
}

\begin{abstract}
The aim of this study was to investigate the effect of lactation number and months on milk yield, somatic cell count (SCC) and udder measurements in Holstein cows. In the study, 30 first lactation and 49 second lactation, totally 79 Holstein cows housing in a farm located in Nigde province (Turkey) were used. Somatic cell count and udder measurements were determined at each visit of the farm per months, while lactation milk yield of each animal was calculated using Test Interval Method. It was observed that the effect of lactation number on lactation milk yield $(P<0.01)$ and SCC $(P<0.05)$ was increased significantly. The effect of lactation number on udder measurements was significant $(P<0.01)$ except front teat length (FTD). Influence of lactation months on milk yield and SCC was increased and statistically significant $(P<0.01)$. The effect of lactation months on distance between front teats (DFT), distance between rear teats (DRT), front teat diameter (FTD), rear teat diameter (RTD) was significant $(\mathrm{P}<0.01)$. A negative correlation was found between SCC and milk yield, front teat clearance from ground (FTC) and rear teat clearance from ground (RTC). On the other hand, a positive correlation was also evident between RTD and distance between front and rear teats. Furthermore, there were positive correlation between milk yield and DFT, DFR, DRT, and FTD, whereas a negative correlation was observed between milk yield and FTC. In conclusion, cows in second lactation showed importantly increased milk yield and SCC as compared to cows in first lactation, whereas FTC and RTC decreased and other udder measurements increased.
\end{abstract}

Key words: Holstein cow, lactation, milk yield, somatic cell count, udder measurement

\section{ABSTRAK}

Tujuan penelitian ini adalah untuk menguji pengaruh angka dan bulan laktasi terhadap produksi susu, somatic cell count (SCC), dan ukuran ambing pada sapi Holstein. Sebanyak 30 ekor sapi Holstein laktasi pertama dan 49 ekor laktasi kedua digunakan pada penelitian ini, sehingga total 79 ekor dikandangkan di peternakan yang terletak di Propinsi Nigde, Turki. SCC dan ukuran ambing diukur pada setiap kunjungan ke peternakan setiap bulan, sedangkan produksi susu tiap ternak dihitung menggunakan Test Interval Method. Pengaruh angka laktasi terhadap produksi susu $(P<0,01)$ dan SCC $(P<0,05)$ secara nyata meningkat. Angka laktasi berpengaruh sangat nyata $(P<0,01)$ terhadap ukuran ambing, kecuali terhadap panjang ujung puting (FTD). Bulan laktasi berpengaruh nyata $(P<0,05)$ meningkatkan produksi susu dan SCC. Bulan laktasi juga berpengaruh nyata $(P<0,05)$ terhadap jarak antar ujung puting (DFT), jarak antar pangkal puting (DRT), diameter ujung puting (FTD), dan diameter pangkal puting (RTD). Korelasi negatif terjadi antara SCC dan produksi susu, serta antara jarak ujung puting dengan tanah (FTC) dan jarak pangkal puting dengan tanah (RTC). Namun demikian, terdapat korelasi positif antara RTD dan jarak antar ujung dan pangkal puting. Selain itu, korelasi positif juga terjadi antara produksi susu dan DFT, DFR, DRT, dan FTD, namun korelasi negatif ditemukan antara produksi susu dan FTC. Dapat disimpulkan bahwa sapi pada laktasi kedua menunjukkan peningkatan produksi susu dan SCC jika dibandingkan dengan pada laktasi pertama, selain itu FTC dan RTC menurun serta ukuran ambing meningkat.

Kata kunci: sapi Holstein, Laktasi, produksi susu, somatic cell count, ukuran ambing

*Corresponding author:

E-mail: aceyhan@nigde.edu.tr or ceyhanayhan@hotmail.com 


\section{INTRODUCTION}

Milk yield is one of the most important factors for sustainability of dairy cattle breeding. Milk yield are affected by many phenotypic and genotypic factors. For instance, breed, age, lactation number and period, properties of teat and udder of cow, management and animal nutrition strategies of farm effect the milk yield and also quality (Koç, 2006).

There are many reports which indicate either the importance of lactation number on milk yield per lactation (Uğur et al., 2006; Koçak et al., 2008; Şahin \& Ulutaş, 2010) or insignificance of lactation number (Sehar \& Özbeyaz, 2005; Koçak et al., 2007). Similarly, Koçak et al. (2007) reported the importance of calving season on lactation milk yield, while others stated the presence of ineffectiveness of calving season on both 305 days milk yield and lactation milk yield (Pelister et al., 2000; Bilgiç \& Alıç 2005; Bakır et al., 2009).

It was reported that lactation number and months had effect on somatic cell count (SCC) in cows and the highest SCC obtains at the second (Kiiman, 1998) and the third lactatiting cows (Eyduran et al., 2005). Environmental factors such as heat stress may also increase SCC (Eyduran et al., 2005; Göncü 2000).

The structural properties of teat and udder are widely used as indirect selection criteria for the resistance against mastitis and lower SCC (Kul et al., 2006). A negative correlation between SCC and udder clearance from the ground were reported (Rupp \& Boichard, 1999).

To our knowledge, only a limited number of studies have focused the detailed relationships among lactation number, udder measurements and SCC in Turkey. Therefore, in this study, the effect of lactation number and months on milk yield, SCC and udder measurements in Holstein cows was investigated.

\section{MATERIALS AND METHODS}

\section{Animals}

In the study, 30 first lactation and 49 second lactation, totally 79 Holstein cows housing in a farm located in Nigde Province (Turkey) were used. Somatic cell count and udder measurements were determined at each visit of the farm per months throughout 10 mo during June 2009-March 2010. Daily milk yield was obtained from computer assisted milking system program.

\section{Feeding Management}

Cows were grouped according to lactation period and fed by total mix ration (TMR) having different feed ingredients (Table 1).

\section{Collecting of Milk Samples and Somatic Cell Count}

Cows were milked three times per day. Individual milk samples were collected monthly at the second milking throughout lactation by special sample collecting cup mounted to automatic milking system and
Table 1. Total Mix Ration (TMR) and calculated nutrient content for lactating cows

\begin{tabular}{lccc}
\hline \multirow{2}{*}{ Feed ingredients } & \multicolumn{3}{c}{ TMR } \\
\cline { 2 - 4 } & $\begin{array}{c}\text { Fresh } \\
(1 \text { month })\end{array}$ & $\begin{array}{c}\text { Peak yield } \\
(2-5 \text { month })\end{array}$ & $\begin{array}{c}\text { Late lactation } \\
(6-10 \text { month })\end{array}$ \\
\hline Alfalfa hay (kg/cow) & 6 & 5 & 5 \\
Corn silage (kg/cow) & 10 & 17 & 12 \\
Wheat straw (kg/cow) & - & - & 2.5 \\
Concentrated feed: Forage & $43: 57$ & $40: 60$ & $46: 54$ \\
Calculated nutrient content & & & \\
Crude protein (\%) & 17.0 & 17.3 & 16.0 \\
ADF (\%) & 19.8 & 19.1 & 24.2 \\
NDF (\%) & 32.3 & 33.1 & 40.5 \\
NEl (kcal/kg) & 2968 & 2932 & 2661 \\
\hline
\end{tabular}

Note: $\mathrm{ADF}=$ Acid detergent fibre, $\mathrm{NDF}=$ Neutral detergent fibre, $\mathrm{NEI}=$ Net energy intake.

transferred into $50 \mathrm{~mL}$ sterile plastic tubes. Somatic cell count of milk samples were measured by DeLaval Cell Counter (DeLaval Int. AB, Tumba, Sweden).

\section{Udder Measurements}

Front teat length (FTL), rear teat length (RTL), front teat diameter (FTD), rear teat diameter (RTD), distance between front teats (DFT), distance between rear teats (DRT), front teat clearance from ground (FTC), rear teat clearance from ground (RTC) and distance between front and rear teats (DFR) were measured before milking by measuring stick and flexible tape as previously reported by Kul et al. (2006); Kuczaj (2000).

\section{Calculation of Lactation Milk Yield}

Lactation milk yield of each animal was calculated by using the Test Interval Method (TIM) that was a reference method by ICAR (ICAR, 2014). The formula to calculate milk yield and duration of lactation (day), daily average milk yield, as shown below.

$$
\begin{aligned}
& \text { Milk Yield }=(\mathrm{A}-1) \mathrm{k}_{1}+\mathrm{a} / 2\left[\mathrm{k}_{1}+\mathrm{k}_{\mathrm{n}}+2\left(\mathrm{k} 2+\mathrm{k} 3+\ldots+\mathrm{k}_{\mathrm{n}}-1\right)\right] \\
& \mathrm{DL}=\mathrm{n}^{*} \mathrm{a}-(\mathrm{a} / 2-\mathrm{A}) \\
& \text { DAMY }=\sum \mathrm{ki} / \mathrm{n}
\end{aligned}
$$

In these formulas, $\mathrm{k}_{1}$ : first control milk yield, $\mathrm{k}_{\mathrm{n}}$ : last control milk yield, DL: duration of lactation (day), A: time between parturition and first control, DAMY: daily average milk yield, $\mathrm{k}_{\mathrm{i}}$ : control total milk yield, n: control number, a: milk control interval.

\section{Statistical Analysis}

The verifying of homogeneity of data were analysed by Kolmogorov-Smirnov test. Logarithmic transformation was used due to abnormal homogeneity of SCC values. Untransformed data were used for average and standard error values, while transformed data were used to determine the significance. First degree auto regressive was used for covariance structure. The correlation between SCC and udder measurement values were analysed by Pearson correlation test. The effects of lac- 
tation number and months on the milk yield, SCC and udder measurements were determined by least squares analysis of variance. The differences between the means of the sub-groups were tested by Duncan test. The results were given in standard least squares means (LSM) and standard error means (SEM). Statistical analysis was performed by SAS program (SAS, 2009).

The model used to analyse the effect of lactation number and months on milk yield, SCC and udder measurements was;

$$
\text { yijk }=\mu+A i+B j+\text { eijk where; }
$$

for milk yield and SCC, udder measurement characteristics, $y=$ traits, $\mu=$ overall mean, $A_{i}=$ lactation number where $\mathrm{i}=1$ and $2, \mathrm{~B}=$ lactation mounts where $\mathrm{j}=$ June to March, and $\mathrm{e}_{\mathrm{ijk}}$ was the random residual.

\section{RESULTS AND DISCUSSION}

Lactation milk yield and lactation period of experimental cows are presented in Table 2. Accordingly, lactation number affected lactation milk yield $(\mathrm{P}<0.05)$, whereas it did not affect length of lactation $(\mathrm{P}>0.05)$ (Table 2).

Udder measurements of the first and the second lactating cows were detected as follows; FTL, 6.07 and $6.04 \mathrm{~cm}$; RTL, 4.84 and $4.93 \mathrm{~cm}$; FTD, 2.56 and $2.67 \mathrm{~cm}$; RTD, 2.51 and $2.63 \mathrm{~cm}$; DFT, 16.47 and $17.99 \mathrm{~cm}$; DRT, 9.34 and $10.40 \mathrm{~cm}$; FTC, 55.42 and $49.71 \mathrm{~cm}$; RTC, 57.14 and $50.08 \mathrm{~cm}$; DFR, 13.15 and $15.37 \mathrm{~cm}$, respectively.

The effects of lactation number and months on milk yield, SCC and udder measurements are given in Table

Table 2. Milk yield and lactation length in Holstein cow

\begin{tabular}{ccc}
\hline Variation source & $\begin{array}{c}\text { Lactation milk } \\
\text { yield }(\mathrm{kg})\end{array}$ & $\begin{array}{c}\text { Lactation length } \\
\text { (day) }\end{array}$ \\
\hline Lactation number & $*$ & NS \\
1 & $7982.83 \pm 378.21$ & $289.93 \pm 5.48$ \\
2 & $9172.45 \pm 290.96$ & $295.88 \pm 4.22$ \\
Average & $8577.64 \pm 238.59$ & $292.90 \pm 3.46$ \\
\hline
\end{tabular}

Note: ${ }^{*}=\mathrm{P}<0.05 ; \mathrm{NS}=$ not significant.
4. It was found that lactation number increased daily milk yield $(\mathrm{P}<0.01)$ and SCC $(\mathrm{P}<0.05)$. The averages of daily milk yield and SCC in the first and second lactating cows were $26.85 \mathrm{~kg} / \mathrm{d}$ and $29.92 \mathrm{~kg} / \mathrm{d}$ and $241 \times 10^{3}$ $\mathrm{mL} /$ cell and $306 \times 10^{3} \mathrm{~mL} /$ cell, respectively. Lactation number did not significantly affect FTL ( $P>0.05)$, on the other hand it significantly $(\mathrm{P}<0.01)$ affected other udder measurements (Table 4).

It was seen that the effect of lactation months on daily milk yield and SCC was increased significantly $(\mathrm{P}<0.01)$. The highest milk yield was observed during the second month of lactation $(34.73 \mathrm{~kg} / \mathrm{d})$. The average SCC was $\leq 200 \times 10^{3} \mathrm{~mL} /$ cell during the second, fourth and ninth month of lactation, whereas it was 200-399 $\times 10^{3} \mathrm{~mL} /$ cell during other months of lactation. It was determined that lactation numbers had significant $(\mathrm{P}<0.01)$ effect on FTD, RTD, DFT and DRT (Table 4). It can be said that especially FTD and RTD is related to change of SCC.

There was a negative correlation between SCC and milk yield $(\mathrm{P}<0.01)$, FTC $(\mathrm{P}<0.05)$ and RTC $(\mathrm{P}<0.05)$, while a positive correlation was found in RTD $(\mathrm{P}<0.01)$ and DFR $(\mathrm{P}<0.05)$. Moreover, a positive correlation was evident milk yield between DFT, DFR, DRT and FTD $(\mathrm{P}<0.01)$, whereas FTC showed a negative and significant $(\mathrm{P}<0.01)$ correlation (Table 3$)$.

The average lactation milk yield $(8577.64 \mathrm{~kg})$ obtained in this study was higher than those in other studies which were reported $6273.0 \mathrm{~kg}$ by Erdem et al. (2007), $6400.3 \mathrm{~kg}$ by Sehar \& Özbeyaz (2005), $7704.3 \mathrm{~kg}$ by Koçak et al. (2007) in different rations, ingredients and nutrient compositions. Higher milk yield may be due to the genetic capacity of the cows, breeding and nutrition condition of farm or three times milking per day. In this study, the duration of lactation (292.9 d) was similar to results (297 d) reported by Sehar \& Özbeyaz (2005) but lower than those reported by Erdem et al. (2007) (308.5 d), and Koçak et al. (2007) (325.6 d).

It was found that the effect of lactation number on daily milk yield $(\mathrm{P}<0.01)$ and lactation milk yield $(\mathrm{P}<0.05)$ was significant, whereas the lactation number did not show any significant effect on duration of lactation $(\mathrm{P}>0.05)$. The studies indicating the maintenance

Table 3. Correlation between udder measurements, milk yield and somatic cell count (SCC) in Holstein cows

\begin{tabular}{|c|c|c|c|c|c|c|c|c|c|c|c|c|}
\hline Traits & & 1 & 2 & 3 & 4 & 5 & 6 & 7 & 8 & 9 & 10 & 11 \\
\hline$\overline{\text { SCC } \log }$ & (1) & 1 & $-0.251^{* *}$ & -0.017 & $-0.102^{*}$ & 0.024 & $-0.105^{*}$ & -0.067 & $0.098^{*}$ & 0.021 & 0.043 & $0.129^{* *}$ \\
\hline MY & (2) & & 1 & 0.042 & $-0.144^{* *}$ & -0.02 & -0.051 & $0.296^{* *}$ & $0.382^{* *}$ & $0.107^{* *}$ & $0.183^{* *}$ & 0.069 \\
\hline FTL & (3) & & & 1 & $-0.091^{*}$ & $0.562^{* *}$ & -0.019 & $0.175^{* *}$ & -0.021 & $0.149^{* *}$ & $0.141^{* *}$ & 0.061 \\
\hline FTC & (4) & & & & 1 & -0.02 & $0.860^{* *}$ & $-0.215^{* *}$ & $-0.352^{* *}$ & $-0.268^{* *}$ & $-0.158^{* *}$ & $-0.098^{*}$ \\
\hline RTL & (5) & & & & & 1 & $-0.141^{* *}$ & $0.209^{* *}$ & $-0.123^{* *}$ & $0.219^{* *}$ & $0.101^{*}$ & $0.155^{* *}$ \\
\hline RTC & (6) & & & & & & 1 & $-0.278^{* *}$ & $-0.273^{* *}$ & $-0.347^{* *}$ & $-0.120^{* *}$ & $-0.145^{* *}$ \\
\hline DFT & (7) & & & & & & & 1 & $0.340^{* *}$ & $0.420^{* *}$ & $0.108^{* *}$ & $0.133^{* *}$ \\
\hline DFR & (8) & & & & & & & & 1 & $0.110^{* *}$ & $0.213^{* *}$ & $0.164^{* *}$ \\
\hline DRT & (9) & & & & & & & & & 1 & $0.127^{* *}$ & $0.156^{* *}$ \\
\hline FTD & (10) & & & & & & & & & & 1 & $0.563^{* *}$ \\
\hline RTD & (11) & & & & & & & & & & & 1 \\
\hline
\end{tabular}

Note: $\mathrm{MY}=$ Milk yield;FTL= Front teat length; FTC= Front teat clearance from ground; $\mathrm{RTL}=$ Rear teat length; RTC $=$ Rear teat clearance from ground; $\mathrm{DFT}=$ Distance between front teat; DRT = Distance between rear teat; FTD= Front teat diameter; $\mathrm{DFR}=\mathrm{Distance}$ between front and rear teats; $\mathrm{RTD}=$ Rear teat diameter; NS $=$ not significant. ${ }^{*}=\mathrm{P}<005,{ }^{* *}=\mathrm{P}<0.01$. 
Table 4. Milk yield, somatic cell count (SCC), and udder measurements at different lactation number and months

\begin{tabular}{|c|c|c|c|c|c|c|c|c|c|c|c|c|}
\hline & $\mathrm{n}$ & $\begin{array}{l}\text { Milk yield } \\
(\mathrm{kg} / \mathrm{d})\end{array}$ & $\begin{array}{c}\text { SCC } \\
\left(\times 10^{3} \text { cell } / \mathrm{mL}\right)\end{array}$ & $\begin{array}{l}\text { FTL } \\
(\mathrm{cm})\end{array}$ & $\begin{array}{l}\text { FTC } \\
(\mathrm{cm})\end{array}$ & $\begin{array}{l}\text { RTL } \\
(\mathrm{cm})\end{array}$ & $\begin{array}{l}\mathrm{RTC} \\
(\mathrm{cm})\end{array}$ & $\begin{array}{l}\mathrm{DFT} \\
(\mathrm{cm})\end{array}$ & $\begin{array}{l}\text { DFR } \\
(\mathrm{cm})\end{array}$ & $\begin{array}{l}\text { DRT } \\
(\mathrm{cm})\end{array}$ & $\begin{array}{l}\text { FTD } \\
(\mathrm{cm})\end{array}$ & $\begin{array}{l}\text { RTD } \\
(\mathrm{cm})\end{array}$ \\
\hline $\mathrm{LN}$ & & $* *$ & * & NS & ** & ** & ** & $* *$ & $* *$ & $* *$ & ** & ** \\
\hline 1 & 30 & $26.85 \pm 0.44$ & $241.24 \pm 41$ & $6.07 \pm 0.1$ & $5.42 \pm 0.3^{\mathrm{a}}$ & $4.84 \pm 0.1^{\mathrm{b}}$ & $57.14 \pm 0.3^{\mathrm{a}}$ & $16.47 \pm 0.2^{\mathrm{b}}$ & $13.15 \pm 0.2^{\mathrm{b}}$ & $9.34 \pm 0.2^{\mathrm{b}}$ & $2.56 \pm 0.02^{\mathrm{b}}$ & $2.51 \pm 0.02$ \\
\hline 2 & 49 & $29.92 \pm 0.34$ & $305.95 \pm 33$ & $6.04 \pm 0.1$ & $49.71 \pm 0.3^{b}$ & $4.93 \pm 0.1^{\mathrm{a}}$ & $50.08 \pm 0.3^{\mathrm{b}}$ & $17.99 \pm 0.2^{\mathrm{a}}$ & $15.37 \pm 0.1^{\mathrm{a}}$ & $10.40 \pm 0.2^{\mathrm{a}}$ & $2.67 \pm 0.02^{\mathrm{a}}$ & $2.63 \pm 0.01$ \\
\hline LM & & ** & ** & NS & NS & NS & NS & $* *$ & NS & $* *$ & $* *$ & $* *$ \\
\hline June & 66 & $33.06 \pm 0.83^{\mathrm{ab}}$ & $280.69 \pm 78^{\mathrm{abcd}}$ & $5.86 \pm 0.1$ & $52.06 \pm 0.6$ & $91 \pm 0.1$ & $52.12 \pm 0.6$ & $18.49 \pm 0.4^{\mathrm{a}}$ & $14.71 \pm 0.3$ & $11.03 \pm 0.4^{\mathrm{a}}$ & $2.70 \pm 0.04^{\mathrm{a}}$ & $2.63 \pm 0.04^{\mathrm{b}}$ \\
\hline July & 55 & $34.73 \pm 0.83^{\mathrm{a}}$ & $184.20 \pm 84^{\mathrm{bcd}}$ & $6.22 \pm 0.1$ & $52.77 \pm 0.6$ & $.12 \pm 0.1$ & $53.09 \pm 0.7$ & $18.69 \pm 0.5^{\mathrm{a}}$ & $14.35 \pm 0.3$ & & $2.69 \pm 0.04^{\mathrm{a}}$ & $2.78 \pm 0.04^{\mathrm{a}}$ \\
\hline & 65 & $30.94 \pm 0.83^{\mathrm{bc}}$ & $227.97 \pm 80^{\mathrm{cd}}$ & $6.03 \pm 0.1$ & $1.68 \pm 0.6$ & $74 \pm 0.1$ & $53.06 \pm 0.6$ & $17.83 \pm 0.4^{\mathrm{ab}}$ & $14.65 \pm 0.3$ & $10.39 \pm 0.4^{\mathrm{ab}}$ & $2.64 \pm 0.04^{\mathrm{ab}}$ & $2.66 \pm 0.04^{b}$ \\
\hline & 79 & $31.73 \pm 0.84^{\mathrm{bc}}$ & $161.82 \pm 81^{\mathrm{d}}$ & $13 \pm 0.2$ & $52.30 \pm 0.6$ & $92 \pm 0.1$ & $53.56 \pm 0.7$ & $17.77 \pm 0.5^{\mathrm{ab}}$ & $14.63 \pm 0.3$ & $10.52 \pm 0.4^{\mathrm{ab}}$ & $2.67 \pm 0.04^{\mathrm{a}}$ & $2.69 \pm 0.04^{\mathrm{ab}}$ \\
\hline & 79 & $29.71 \pm 0.84^{\mathrm{cd}}$ & $268.17 \pm 71^{\mathrm{abcd}}$ & $6.02 \pm 0.1$ & $52.50 \pm 0.6$ & $4.77 \pm 0.1$ & $54.18 \pm 0.6$ & $17.62 \pm 0.4^{\mathrm{ab}}$ & $14.37 \pm 0.3$ & $9.86 \pm 0.3^{\text {cd }}$ & $2.70 \pm 0.04^{a}$ & $2.65 \pm 0.04^{\mathrm{b}}$ \\
\hline & 78 & $27.49 \pm 0.83^{\mathrm{d}}$ & $309.47 \pm 75^{\mathrm{ab}}$ & $6.29 \pm 0.1$ & $53.19 \pm 0.6$ & $4.96 \pm 0.1$ & $55.34 \pm 0.6$ & $17.67 \pm 0.4^{\mathrm{ab}}$ & $14.46 \pm 0.3$ & $9.47 \pm 0.4^{\mathrm{cd}}$ & $2.66 \pm 0.04^{\mathrm{ab}}$ & $2.57 \pm 0.03^{\mathrm{bc}}$ \\
\hline & 63 & $24.48 \pm 0.84^{\mathrm{e}}$ & $365.96 \pm 80^{\mathrm{ab}}$ & $6.14 \pm 0.1$ & $52.70 \pm 0.6$ & $4.99 \pm 0.1$ & $53.76 \pm 0.7$ & $16.88 \pm 0.5^{\mathrm{bc}}$ & $14.16 \pm 0.3$ & $9.53 \pm 0.4^{\mathrm{cd}}$ & $2.55 \pm 0.04^{\mathrm{bc}}$ & $2.49 \pm 0.03^{\mathrm{cd}}$ \\
\hline January & 49 & $24.15 \pm 0.87^{e}$ & $356.14 \pm 87^{\mathrm{ab}}$ & $5.82 \pm 0.2$ & $52.98 \pm 0.7$ & $4.86 \pm 0.1$ & $53.50 \pm 0.7$ & $15.78 \pm 0.5^{c}$ & $14.02 \pm 0.4$ & $10.05 \pm 0.4^{\mathrm{ab}}$ & $2.51 \pm 0.04^{c}$ & $2.43 \pm 0.03^{\mathrm{ef}}$ \\
\hline February & 48 & $24.69 \pm 0.92^{\mathrm{e}}$ & $182.33 \pm 94^{\mathrm{abc}}$ & $6.06 \pm 0.2$ & $52.93 \pm 0.7$ & $4.79 \pm 0.1$ & $53.87 \pm 0.7$ & $15.70 \pm 0.5^{c}$ & $13.70 \pm 0.4$ & $8.65 \pm 0.4^{\mathrm{d}}$ & $2.55 \pm 0.04^{\mathrm{bc}}$ & $2.45 \pm 0.04^{\mathrm{ef}}$ \\
\hline March & 45 & $22.88 \pm 1.00^{\mathrm{e}}$ & $399.22 \pm 93^{a}$ & $5.98 \pm 0.2$ & $52.60 \pm 0.7$ & $4.79 \pm 0.1$ & $53.62 \pm 0.8$ & $15.90 \pm 0.5^{c}$ & $13.56 \pm 0.4$ & $8.47 \pm 0.4^{\mathrm{d}}$ & $2.49 \pm 0.04^{\mathrm{c}}$ & $2.36 \pm 0.04^{\mathrm{f}}$ \\
\hline Average & & $28.39 \pm 0.28$ & $273.60 \pm 27$ & $6.05 \pm 0.1$ & $52.57 \pm 0.2$ & $4.89 \pm 0.0$ & $53.60 \pm 0.2$ & $17.23 \pm 0.2$ & $14.26 \pm 0.1$ & $9.87 \pm 0.1$ & $2.62 \pm 0.01$ & $2.57 \pm 0.01$ \\
\hline
\end{tabular}

Note: FTL= Front teat length; FTC= front teat clearance from ground; RTL= rear teat length; RTC= rear teat clearance from ground; DFT= distance between front teat; DRT= distance between rear teat; FTD= front teat diameter; $\mathrm{DFR}=$ distance between front and rear teats; $\mathrm{RTD}=$ rear teat diameter; $\mathrm{LN}=$ lactation number; $\mathrm{LM}=$ lactation month; $\mathrm{NS}=$ not significant; $\mathrm{a}, \mathrm{b}, \mathrm{c}, \mathrm{d}, \mathrm{e}, \mathrm{f}=$ differences between different letters in the same column is significant. ${ }^{*}=\mathrm{P}<005 ;{ }^{* *}=\mathrm{P}<0.01$.

of positive effect of lactation number on milk yield from the first lactation to the third lactation or fourth even fifth lactation (Khattab \& Ashmawy 1988) were consistent with the results of present study. Gürses \& Bayraktar (2012) reported that the comparative sort of lactation number was $2>1>3>4>5>6+$ according to $305 \mathrm{~d}$ milk yield. Khattab \& Ashmawy (1988) stated that when lactation number and age increased, body weight, feed intake and milk secretion capacity of udder increased.

The effect of lactation number on SCC was found to be significant in this study $(\mathrm{P}<0.05)$. Similar results were reported in other studies (Koç \& Kızılkaya 2009; Eyduran et al., 2005; Eyduran, 2002; Göncü, 2000). It was determined that the effect of lactation number was not significant only for FTL and significant for other udder measurements $(\mathrm{P}<0.01)$, whereas FTC and RTC decreased and other udder measurements increased in the second lactating cows. It is suggested that the increment of milk yield in the second lactating cows may be associated with changes in udder measurements. Özbeyaz et al. (1998) reported that udder clearance from ground tended to decrease, when lactation number increased.

The effect of lactation months on daily milk yield was found to be significant $(\mathrm{P}<0.01)$. It was determined that milk yield was high during the first and the second months of lactation, and it tended to decrease during 3-6 mo of lactation and clearly decreased 7-10 mo of lactation. The effect of lactation months on SCC was significant $(\mathrm{P}<0.01)$. The average SCC during the second (July), fourth (September) and ninth (February) months was $\leq 200 \times 10^{3}$ cell $/ \mathrm{mL}$, while it was $200-399 \times 10^{3}$ cell/ $\mathrm{mL}$ during other months of lactation. The last month of lactation showed the highest SCC. Koç \& Kizılkaya (2009) and Ural (2013) reported that the effect of months of lactation was significant on SCC $(\mathrm{P}<0.01)$. Differences in SCC across lactation months can be explained the oc- currence of rainfall and hours of sunshine which affect contamination of the teat ends by the mastitis causing organisms. Also, Göncü (2000) and Eyduran (2002) indicated that the season was an important factor affecting the SCC. Eyduran et al. (2005) reported that average SCC in August was two folds higher than average SCC in December and heat stress during summer season affected SCC. In the present study, it was seen that lactation months were effective in increasing SCC rather than season. The discrepancies in this study may be related to climate of the region or the reflection of reducing dilution effect following decreasing milk yield after the third month of lactation. It was determined that the effect of lactation months was significant on DFT, DRT, FTD and RTD $(\mathrm{P}<0.01)$, while it was not significant in other udder measurements. Moreover, it was seen that DFT, DRT, FTD and RTD decreased in the upcoming months of lactation. It may be suggested that this changes occurs parallel to reducing milk yield.

In the present study, SCC showed a negative correlation with FTC and RTC $(\mathrm{P}<0.05)$, while RTD $(\mathrm{P}<0.01)$ and DFR $(\mathrm{P}<0.05)$ had positive correlation (Table 3$)$. The negative correlation between udder clearance from ground and SCC was reported in other studies (Rupp \& Boichard, 1999). Kul et al. (2006) reported that structural properties of udder were indirect selection criteria for resistance to mastitis and low SCC level. It was found that a negative correlation was evident between SCC and milk yield $(\mathrm{P}<0.01)$. Juozaitiene et al. (2006) reported the similar negative relation between SCC and milk yield. In this study, a positive correlation between milk yield and DFT, DRT, FTD, DFR was evident $(\mathrm{P}<0.01)$, whereas milk yield showed a negative correlation with FTC $(\mathrm{P}<0.01)$. It is suggested that the increment in milk yield may be closely associated with physiological development of udder. 


\section{CONCLUSION}

There was a negative correlation between SCC and some udder measurements like FTL, FTC, RTC, and DFR. It is suggested that the use of SCC and same udder measurements as a selection criteria for the genetic selection of dairy cows to improve the milk yield.

\section{ACKNOWLEDGEMENT}

The authors would like to thank the Department of Scientific Research Projects, Nigde University for funding the project (Project Number: BAP99/14).

\section{REFERENCES}

Bakır, G., A. Kaygısız, \& S. Çilek. 2009. Milk yield traits of Holstein cattle reared at Tahirova State Farm in Balikesir province in Turkey. J. Anim. Vet. Advances. 8: 2369-2374.

Bilgiç, N. \& D. Alıç. 2005. Milk yield traits of Holstein Friesian cows raised in Polatlı State Farm. Selçuk Üniv. Ziraat Fak. Derg.19: 116-119.

Erdem, H., S. Atasever, \& E. Kul. 2007. Milk yield and fertility traits of Holstein cows raised at Gokhoyuk State Farm 1. Milk yield traits. Ondokuz Mayıs Üniv. Zir. Fak. Derg. 22: 47-54.

Eyduran, E., T. Özdemir, K. Yazgan, \& S. Keskin. 2005. The effects of lactation rank and period on somatic cell count (SCC) in milks of Holstein cows. YYU Vet. Fak. Derg. 16:61-65.

Gürses, M., \& M. Bayraktar. 2012. some milk production and reproductive traits of Holstein cattle raised in different regions of Turkey. Kafkas Univ. Vet. Fak. Derg.18: 273-280.

ICAR. 2014. International Committee for Animal Recording (2014): Guidelines approved by the General Assembly held in Berlin, Germany, on 30 May 2014.

Juozaitiene, V., A. Juozaitis, \& R. Micikeciene. 2006. Relationship between Somatic cell count and milk production or morphological traits of udder in black-and-white cows. Turk. J. Vet. Anim. Sci. 30:1-5.

Khattab, A. S. \& A. A. Ashmawy. 1988. Relationships of days open and days dry with milk production in Friesian cattle in Egypt. J. Anim. Breed and Genetics.105: 300-305. http:// dx.doi.org/10.1111/j.1439-0388.1988.tb00302.x
Kiiman, H. 1998. Causes of a High SCC. 49th European Association for Animal Production. Warsaw, Polland.

Koç, A., \& K. Kizilkaya. 2009. Some factors influencing milk somatic cell count of Holstein Friesian and Brown Swiss cows under the Mediterranean climatic conditions. Archiv Tierzucht. 52:124-133.

Koç, A. 2006. Lactation milk yields and somatic cell counts of Holstein Friesian and Brown-Swiss cattle reared in Aydın province. Animal Production 47: 1-8.

Koçak, S., M. Tekerli, C. Özbeyaz, \& I. Demirhan. 2008. Some production traits of Holstein, Brown-Swiss and Simmental cattle reared in Lalahan Livestock Research Institute. Journal of Lalahan Livestock Research Institute 48: 51-57.

Koçak, S., B. Yüceer, M. Uğurlu, \& C. Özbeyaz. 2007. Some production traits of Holstein cows reared in Bala State Farm. Journal of Lalahan Livestock Research Institute 47: 9-14.

Kuczaj, M. 2003. Analysis of changes in udder size of highyielding cows in subsequent lactations with regard to mastitis. Electronic J. Pol. Agric. Univ. Ser. Anim. Husb. 6(1).

Kul, E., H. Erdem, \& S. Atasever. 2006. Effect of different udder traits on mastitis and somatic cell count in dairy cows J. of Fac. of Agric. OMU. 21: 350-356.

Pelister, B., A. Altınel, \& H. Güneş. 2000. An investigation into the milk yield characteristics of Holstein cattle of different origins under commercial farm conditions. J. Fac. Vet. Med. İstanbul Univ. 26: 543-559.

Rupp, R. \& D. Boichard. 1999. Genetic parameters for clinical mastitis, somatic cell score, production, udder type traits, and milking ease in first lactation Holsteins. J. Dairy Sci. $\quad 82: 2198-2204$. http://dx.doi.org/10.3168/jds.S00220302(99)75465-2

Şahin, A., \& Z. Ulutaş. 2010. Fertility and milk yield traits of Holstein cattle raised in Polatli State Farm. Anadolu J. Agric. Sci. 25:202-212.

SAS. 2009. SAS User's Guide: Statistics. Version 9.2 Edition. SAS Inst. Inc. Cary. NC.

Sehar, Ö., \& C. Özbeyaz. 2005. Some production traits of Holstein cows at a State Farm in Middle Anatolian Conditions. Journal of Lalahan Livestock Research Institute 45: 9-19.

Uğur, F., S. Akkuş, \& O. Erdaş. 2006. Effects of days open on milk yield traits of Holstein Friesian cattle. Atatürk Univ. J. the Agricultural Faculty 37: 177-180.

Ural, D.A. 2013. The relationships among some udder traits and somatic cell count in Holstein-Friesian Cows. Kafkas Univ. Vet. Fak. Derg. 19: 601-606. 